\title{
BRONQUITE NO PARANÁ-BRASIL ANÁLISE SOBRE INCIDÊNCIA DE INTERNAÇÃO
}

\author{
BRONCHITIS IN PARANÁ-BRAZIL ANALYSIS OF HOSPITALITY INCIDENCE
}

Mariane Souza Marques ${ }^{1 *}$, Emanoelle Aparecida Palangani ${ }^{1}$, Ana Laura Faria Vieira ${ }^{1}$, Paulo Sérgio Belini ${ }^{2}$.

'UNINGÁ - Centro Universitário Ingá, Maringá, PR, Brasil.

'Universidade de Vassouras, Vassouras, RJ, Brasil.

*mari.s.m@hotmail.com

\section{RESUMO}

A bronquite é caracterizada por sintomas respiratórios persistentes e limitação ao fluxo de ar nos pulmões causados por significativa exposição a partículas ou gases nocivos, principalmente a fumaça do cigarro. O presente estudo avaliou a incidência de internações de bronquite entre as faixas etárias 10 a 14 anos e 15 a 19 anos nos anos de 2014 a 2019, assim como, a predominância entre sexo e raça no estado do Paraná. Houve coleta e análise de dados do DATASUS, recorrendo ao intervalo entre 2014 a 2019. Como critério de inclusão houve analise dos conteúdos de internações, sexo e raça comparando entre as faixas etárias de 10 a 14 anos e 15 a 19 anos. Em consideração ao número de internações referentes a bronquite entre 10 a 14 anos em relação ao Paraná no espaço temporal de 2014 (89) a 2019 (40) houve redução de 55,05\% dos casos, já analisando a faixa etária de 15-19 anos em 2014 (102) a 2019 (50) houve redução de 50,98\%. A análise dos sexos na faixa etária de 10 a 14 anos, o sexo masculino em 2014 (43) a 2019 (21) diminuiu em 51,16\%; o sexo feminino, na mesma faixa etária, em 2014 (46) a 2019 (19) houve redução em 58,69\%. Analisando a faixa etária de 15 a 19 anos para o sexo masculino no espaço temporal de 2014 (44) a 2019 (24) temos redução de 45,45\%; analisando o sexo feminino, na mesma faixa etária, e no espaço temporal de 2014 (58) a 2019 (26), temos a redução de $55,17 \%$. Analisando as raças na faixa etária de 10 a 14 anos; a raça branca, no espaço temporal de 2014 (63) a 2019 (21), apresentou redução em 66,66\%; a raça preta no espaço temporal de 2014 apresentou 2 casos, enquanto 2019 não houve casos; a raça parda, no espaço temporal de 2014 (6) a 2019 (20), houve aumento em 233\%; a raça amarela, de 2014 a 2019 não houve casos; enquanto a raça indígena os dados são inexistentes. Analisando a faixa etária de 15 a 19 anos; a raça branca em 2014 (69) a 2019 (30), apresentou redução em 56,52\%; a raça preta no espaço temporal de 2014 a 2019 não apresentou casos; a raça parda no espaço temporal de 2014 (9) a 2019 (3), apresentou redução em 66,66\%; a raça amarela permaneceu com 1 caso em 2014 a 2019; enquanto a raça indígena os dados são inexistentes. Com base na análise dos dados do DATASUS referente ao conteúdo de internações, pode se concluir que no período de 2014 a 2019 houve redução em mais de $50 \%$ dos casos tanto na faixa-etária de 10 a 14 anos, quanto de 15 a 19 anos, sendo a redução de 55,05\% e 50,98\%, respectivamente. Além disso, em ambas as faixas etárias o sexo feminino foi o que apresentou maior redução dos casos. Por fim, concluiu-se também que entre as raças, na faixa etária de 10 a 14 anos, a parda 
apresentou um aumento de casos, totalizando 20 casos, enquanto que na faixa etária de 15 a 19 anos, a raça parda foi a que apresentou maior redução $(66,66 \%)$.

Palavras-chave: Doença pulmonar. Bronquite. Enfisema. Doença respiratória. Pesquisa sobre serviços de saúde. 